\title{
9/11 UND die Folgen IN DER POPMUSIK II. O-TÖNE
}

\section{Thomas Phleps}

I've always disagreed with folks who've said

This world is saved by songs

One thing I've learned from all of this

Is I guess I must be wrong

Some people think it's dangerous

These things we sing and write

The pen is mightier than the sword

And I'm wielding mine tonight

No, I didn't make the list

Though I'm really not surprised

I guess that means I can resist

When they've silenced all these other guys

I'm taking it well, I'm giving 'em hell

It's the only sane solution

So here's a song, now sing along

And join the revolution

,Come on, people, now smile on your brother

Everybody get together and love one another right now<

(John McCutcheon: »The List«, 19.9.2001)

How many songs it takes for you to see

You can bomb the world to pieces

You can't bomb it into peace

We can chase down all our enemies

Bring them to their knees

We can bomb the world to pieces

But we can't bomb it into peace

Whoa we may even find a solution

To hunger and disease

We can bomb the world to pieces

But we can't bomb it into peace

(Michael Franti \& Spearhead: »Bomb The World «, 9/2001) 


\section{Quantensprung, am.}

It's all that I can do, 'cause the world's all out of tune.

You have my heart, you have my prayers.

It's all that I can do, 'cause the world's all out of tune

(Jeremy Borum: »Out Of Tune«, 9/2001)

They were the tallest

Powerful and strong

Two symbols of American pride

Our hearts were broken

Our souls will mourn

The day the twins died

(Morris Walker: »The Twins: A Song For America«, 9/2001)

Side by side - they stood, for all the world to see

Side by side - sentinels, of the land of the free

Side by side - they crumbled, and the whole world cried

Side by side - they tumbled, but their spirit - never died

(William McMillan: »Side By Side«, 9/2001)

It's the home of 9-11, the place of the lost towers

We still banging, we never lost power, tell 'em

Welcome to New York City, welcome to New York City

Y'all fuckin' with BK's banger and Harlem's own gangster

Now that's danger there's nothing left to shape up

Welcome to New York City, welcome to New York City

(Cam'Ron feat. Jay-Z \& Juelz Santana: »Welcome To New York«, 5/2002)

This is my right

A right given by God

To live a free life

To live in freedom

Talkin' about freedom

I'm talkin' 'bout freedom

I will fight

For the right

To live in freedom

(Paul McCartney: »Freedom«, 10/2001) 
Where were you when the world stopped turnin'

That September day?

Out in the yard with your wife and children

Or working on some stage in L.A.?

Did you stand there in shock at the sight of that black smoke

Rising against that blue sky?

Did you shout out in anger, in fear for your neighbour

Or did you just sit down and cry?

(Alan Jackson: »Where Were You (When The World Stopped Turning)«, 9/2001)

911, the world ended

And started all over again

We saw the towers fall; I felt small

Thank God, you've got an angel for a friend

(Gotham Artists: »911«, 10/2001)

On the eleventh of September, in the year two-thousand one

We woke to the worst of nightmares in the early hours of dawn

From Virginia to Manhattan in our town the fires raged

Do you remember where you were on that day the universe changed?

(Ethan Daniel Davidson: »September 11 - The Day The Universe Changed«, 9/2001)

A nation saw evil in September skies

By some faceless coward who'll soon pay the price

For challenging the towers of American pride

The day America cried

Why, why, why, oh why

(Jim Peterik \& Johnny VanZant: »The Day America Cried «, 10/2001)

The sky was falling and streaked with blood

I heard you calling me, then you disappeared into the dust

Up the stairs, into the fire

Up the stairs, into the fire

I need your kiss, but love and duty called you someplace higher

Somewhere up the stairs, into the fire

May your strength give us strength

May your faith give us faith

May your hope give us hope

May your love give us love

(Bruce Springsteen: »Into The Fire«, 7/2002) 


\section{Quantensprung, dt.}

"Der Song von Curse Nichts wird mehr so sein wie es war ist am 16.09.01 entstanden. Und wir wollen, dass ihr euch alle das Ding runterladet, brennt, anhört, verteilt und an jeden schickt, den ihr kennt. HipHop hat eine Verantwortung. Helft uns, in Angedenk der schrecklichen Terroranschläge in den USA, dies mit diesem Song allen wieder ins Gedächtnis zu rufen. Peace, Curse"

(http://www.curse.de/single2001/index.html)

Ich will euch gar nichts erzählen von irgendwelchen terroristischen Taten, denn wir habn's alle gesehen im Fernsehen, passiert in den Staaten. Ich hab direkt und live die zwei Türme stürzen sehen, Menschen flüchten sehen und war wie gelähmt aus Angst um die Freunde von mir, die drüben leben. Nach kurzem Überlegen wird mir bewusst: niemand ist überlegen, Stolz bringt uns zu Fall. Ich denk nach übers Leben. Ich hör euch sagen: »Es war bin Laden«. Doch Schuld an der Scheiße sind nicht nur die, sondern auch wir und zwar auf gleiche Weise, denn überheblich sein und Rechte mit Füßen treten, geht nicht auf lange Zeit, es ist klar zu sehen und wir büßen eben. Das soll jetzt gar nicht ironisch sein. Die Gewalt trifft die Falschen. Ich geb'n Fuckfinger an alle Politiker! Es ist einfach keine Zeit mehr für Trennung und Grüppchenbildung. Ich will gute Bildung. Bringt den Kleinen bei, was gemeinsam heißt. Das ganze Leid ist zu viel für mich, ich ertrag's nicht mehr! Wer jetzt noch rapt ohne Sinn, ist genauso schlimm wie die Nazis!

Nichts wird mehr so sein, wie es war, Und niemand wird so bleiben, wie er war, Wahrscheinlich sehen wir vieles jetzt klar, Vielleicht nicht, aber nichts wird mehr so sein, wie es war.

Und ich krieg jeden Tag von Menschen Anrufe, die nach Verschwörungstheorien mit 23 drin suchen. Ich kann's nicht mehr hören, verschwend nicht die Zeit und den Geist an Unsinn. Ich denk an die, die verstarben, und dank für die, die gesund sind, bet für den Rest der Welt, dass der Friedenprozess noch hält, dass sich endlich mal was um Menschlichkeit dreht, nicht bloß um viel Geld, dass der Vergeltungsschlag nicht unüberlegt ist. Ich seh Bilder von Afghanistan und die Hungersnot des Volkes bewegt mich. . .

(Curse: »Nichts wird mehr so sein wie es war«, 9/2001)

"Dieser Song ist ein Aufruf zu Frieden und Toleranz und es liegt uns viel daran, dass Ihr ihn hört und Euch einmal über die Hintergründe dieser grausamen Anschläge Gedanken macht.«

(http://www.diekomplettebandbreite.de)

Im Jahre 2001, am 11. September, flogen zwei Flugzeuge in das World Trade Center. Verheerender Flug islamistischer Terroristen, die mit 'ner dritten Maschine ein Loch ins Pentagon rissen. Tausende Zivilisten umgekommen in Trümmern, New Yorks Twin Tower verschwinden aus der Skyline für immer. Nie mehr wird es so, wie es mal war auf Ground Zero. Sarg für 6000 Seelen und die Frage nach dem Wieso? Wieso, Mann, wenn Islam Frieden heißt, machen diese religiösen Todesboten so'n Scheiß? Ich weiß die Antwort nich genau, doch Mister Bush, ich habe dat Gefühl, Mann, du hast da wat gewusst, hey! 
Mister Bush, hast du es wirklich nicht gewusst, Wozu Menschen im Stande sind aus Verzweiflung und Frust?

Mister Bush, hast du et nich geahnt?

Sag mir, Mister Bush, warum ham die dat geplant? ...

Bitte, Mister Bush, bitte schieß nich aus der Hüfte und bitte schick nich wieder deine Bomber in die Lüfte. Bitte, Bush, verzichte auf die Fehler der Geschichte, denn Bomben für den Frieden sind sicher nich so dat Richtige, da Vergeltung nur noch mehr den Hass und den Terror schürt. Et gebührt der einzig letzten großen Weltmacht, dat sie, außer um sich selbst, sich auch Sorgen um die Welt macht. . .

(Die komplette Bandbreite: »Mister Bush«, 10/2001)

Der Tag, an dem die Erde still stand, war der Tag, an dem ich dich verlor.

Die Nacht, die mich nicht sterben ließ, sie nahm dich für immer von mir fort.

Der Traum, den wir beide träumten, von einer Welt, die nur den Frieden kennt, Dieser Traum, der ist nun zerbrochen, denn ohne dich zerbricht auch meine Welt.

Ich hör noch immer deine Stimme aus dem Handy. Du sagst:

»Liebling, vergiss mich nicht!

Ich wär jetzt so gern bei Dir, doch dafür ist es jetzt zu spät

Vergiss mich nicht, ich liebe dich, ich liebe dich so sehr!«

Der Tag, an dem die Erde still stand, war der Tag, an dem ich dich verlor.

Niemals vergess ich diesen Tag, als ich dir meine Liebe schwor.

Der Tag, an dem die Sonne weinte, umhüllt von Asche und von Staub,

Er hat mir alles genommen, woran ich jemals geglaubt.

[Sie:] Oh mein Liebling, musst nicht weinen, ich werd immer bei dir sein.

Wir sehn uns wieder in einer andern Welt und dann sind wir für immer vereint.

Der Tag, an dem die Erde still stand, war der Tag, an dem ich dich verlor.

Und doch werd ich dich nie vergessen, meine Liebe zu dir, sie ist so groß.

Ich hör noch immer deine Stimme, sie sagt: »Ich lass dich nie allein,

Denn bis ans Ende aller Tage wirst du in meinem Herzen sein."

(Christian Anders ft. Jenna Kartes: »Der Tag, an dem die Erde stillstand«, 3/2002)

Als die Kubakrise die Welt bedrohte, war ich grade vier, Und dann ging es weiter in Vietnam und dann gab's auf Hawaii kein Bier. Ich blieb sitzen und sagte: "Lieber Gott, mir wird das alles zu viel!« Also, ich hatte schon vor dem 11. September oft ein Scheißgefühl. . .

Dieser ganze Urlaubswahnsinn, da wurde gebucht und gebucht.

Das sah doch nie nach Ferien aus, das hatte mehr was von Massenflucht.

Das soziale Klima war immer schon eigentlich viel zu kühl.

Also, ich hatte schon vor dem 11 . September oft ein Scheißgefühl.

Und was ist mit Aids und BSE, was ist mit den hungernden Massen?

Was ist mit all den Idioten, die andere Rassen hassen?

Deshalb laufe ich noch lange nicht Amok, das ist eigentlich nicht mein Stil.

Aber ich hatte schon vor dem 11. September oft ein Scheißgefühl.

(Funny van Dannen: »11. September«, 9/2002) 
$\mathrm{Na}$, was sagen Sie denn nun:

11. September.

Angriff auf das Herz unserer Zivilisation.

World Trade Center. Pentagon.

Da ist doch wohl auch Euereins die Spucke weggeblieben,

Bei so was völlig Unerwartetem.

Nichts ist seitdem mehr so wie vorher.

Das meinen Sie doch auch,

Oder?

Nach diesem Quantensprung in eine neue Zeit, in eine neue Dimension.

Yes, Sir.

Ein neues Zeitalter ist angebrochen,

Und das ist mehr als ein Gezeitenwechsel.

Die Theorien, Werte und Begriffe von dunnemals:

Erledigt.

Zum Beispiel nichts mehr da mit so einem Geschwafel:

Wie konnte es dazu überhaupt nur kommen?

Was sind die Ursachen für solche Wahnsinnstaten?

Eure Sprüche aus der Mottenkiste aus dem vorigen Jahrhundert:

Imperialismus, Ausbeutung,

Jahrzehntelange, ja jahrhundertlange Unterdrückung,

Hier die Superreichen, dort das Heer der Bitterarmen,

Die will keiner jetzt mehr hören.

Und schon gar nicht solche Selbstanklagen wie:

Wir haben denen schließlich auch was angetan

Und pipapo.

Nein!

Entschlossenheit, gesunde Rache, Kampfbereitschaft.

Das sind die neuen Energien. . .

Klare Konturen gibt es wieder.

Schluss mit der Unübersichtlichkeit,

Den Differenzen und den ewigen Bedenken:

Vielleicht ja, vielleicht nein,

Wer weiß denn überhaupt. . .

Eindeutigkeit,

Jawohl Eindeutigkeit,

Da haben sich alle nach gesehnt.

Das Gute und das Böse,

Das ewige Schema allen Lebens, Fühlens, Denkens und der Politik.

Freund - Feind,

Und Letzterer ist klar erkennbar für die Leute.

Diesmal mit Kaftan, Rauschebart und Turban.

So wie Karl May ihn schon beschrieben hat:

Der alte Mürbarek, so hieß der damals.

Und heute heißt er?

$\mathrm{Na}$... .

(Franz Josef Degenhardt: »Quantensprung«, 8/2002) 


\section{Vergeltung}

This is the United States of America

The land of the brave and the free

We believe in God and we believe in justice

We believe in liberty

You've been pulling our chain

We should've done something 'bout you a long time ago

But now the flag's flying high and the fur's gonna fly

And soon the whole world's gonna know

This ain't no rag, it's a flag

Old Glory red, white and blue

The stars and the stripes when it comes to a fight

We can do what we have to do

Our people stand proud

The American crowd is faithful, loyal and tough

We're good as the best and better than the rest

And you're gonna find out soon enough

When you look up in the sky

And you see the eagle fly

You better know he's a heading your way

Cause this ain't no rag it's a flag

And it stands for the USA

USA, USA, USA, USA

(Charlie Daniels Band: »This Ain't No Rag It's A Flag«, 9/2001)

"I' $m$ a very patriotic person and I just couldn't believe it when I saw those two towers go down, I got mad and then I got a lot of resolve (and wrote the song). It's about, >You guys shouldn't have done that, you're playing with the big boys now.< We've been attacked, now it's our turn. That's the way I feel."

(Charlie Daniels; http://www.canoe.ca/JamMusicArtistsD/daniels_charlie.html)

"I wrote this song as a gift to our veterans. My father was one of them ... This song never flew planes into buildings. It's just a song."

(Toby Keith; http://www.thetimesnews.com/2002/02-09/02-09-10/accent-4.html)

Oh, Justice will be served and the battle will rage

This big dog will fight when you rattle his cage

You'll be sorry that you messed with the US of A

'Cuz we'll put a boot in your ass, it's the American way

Hey Uncle Sam put your name at the top of his list

And the Statue of Liberty started shaking her fist

And the eagle will fly, and there's gonna be Hell

When you hear Mother Freedom start ringing her bell!

And it'll feel like the whole wide world is raining down on you

Brought to you courtesy of the Red, White and Blue

(Toby Keith: »Courtesy Of The Red, White, \& Blue (The Angry American)«, 7/2002) 
We're gonna catch Osama Bin Laden, hang him by the yin-yang!

We're gonna fuck Bin Laden, and make the little bastard pay!

We're gonna kill Osama Bin Laden, hang him by the yin-yang!

He can run, he can hide, we're gonna catch him anyway!

Bin Laden, you raghead... FUCK! You're life is fixin' to suck!

You're gonna go down, Bin Laden, and that's a fact!

An ass-kickin' is comin' to you! Took your best shot, but now you're thru!

This is America, boy! Didn't you know that!!!!

(Johnny Rebel: »Infidel Anthem (Fuck You, Osama Bin Laden!)«, 2002)

"Johnny Rebel, real name C. J. Trahan, is a singer and songwriter from Lousiana who recorded several songs with racist and segregationist themes, supporting rwhite power and the Ku Klux Clan. The Anti-Defamation League calls him the original American hate musician." (http://encyclopedia.thefreedictionary.com/Johnny\%20Rebel)

For the Afro-American, Latino, and white

If it was all wrong, I guess now we right

There's no time to run, now it's time to fight

Instead of the Twin Towers we gonna build triplets

And show asperity to them evil ass snipples

It's on, it's on

The sun that didn't shine

Don't blame it on the rain

To all those that lost their lives

In our hearts you will remain ...

Now you can't stop the land of the free

Home of the prophet

Never lay down for no one

Represent the warriors

We are as people

Show 'em the flag, flash 'em the eagle

That's the stamp we all carry

Black, white, Puerto Rican

Son whatever it be

We all married

Send the ships and the planes in

Bomb, if we must

And remember, we doing this for the lives they touched

And ruined

Families left, empty spaces

Daddy's gone now

You motherfucker's got balls

And we love to break them

You cowards fucked with the wrong country

You brought the smoke, now it's time for munchies

Uh, what!

(Cash \& Computa: »Ground Zero (In Our Hearts You Will Remain)«, 10/2001) 
Draft me! I wanna fight for my country

Jump in a humvee and murder those monkeys!

Draft me! I'm too dedicated to fail

Justice must prevail (Justice must prevail!)

Yo, I wanna get drafted, I wanna see somebody get they ass kicked

With standard military tactics

Fuck brass knuckles, I'll punch you with brass fists

Totally flowin' with my emotions in my moment of madness

I'll wake up the whole barracks, murder you on your matress

And look at you like, »What's the matter? «

You better go back to your bed, before I have to act up

You might be the next one to get ripped you jacker!

(Canibus: »Draft Me«, 11/2001)

Osama - yo' mama didn't raise you right

When you were young she must have wrapped yo' turban too tight

She should have kept you home on those Arabian nights

It's plain to see - you need some therapy

Osama - yo' mama could have done a lot better

Though I bet every day you did somethin' to upset her

By the way, we got an answer to your anthrax letter

New York City's where it's from - it's called a smart bomb

(Ray Stevens: »Osama - Yo' Mama«, 10/2001)

"I' $m$ a peace loving man and I thank our troops and the veterans before them for the freedom they have given all of us. As the father of a 22-month old girl, Lily Pearl, I want my child to grow up with the same sense of peace and confidence that I enjoyed."

(Clint Black; http://www.blogcritics.org/archives/2003/03/26/103102.php)

This terror isn't man to man

They can be no more than cowards

If they won't show us their weapons

We might have to show them ours

It might be a smart bomb

They find stupid people too

And if you stand with the likes of Saddam

One just might find you

I rock, I rack 'em up and I roll

I'm back and I'm a high tech GI Joe

I've got infrared, I've got GPS

And I've got that good old fashioned lead

There's no price too high for freedom

So be careful where you tread

(Clint Black: »I Raq And I Roll«, 3/2003) 
Come, Mr. Taliban, turn over bin Laden

Colin Powell gonna bomb his home

Come, Mr. Taliban, turn over bin Laden

Payback come, and we drop the bomb

Lift one bomb, two bomb, three bomb, four

Payback come when we drop the bomb

Six bomb, seven bomb, hit the floor

Cruise missile knocking at your door

Pay - we say pay-o

Kick your ass, then we wanna come home

(KOMP Rock \& Roll Morning Show: »Osama Bin Laden Bomb Song«, 10/2001)

"I literally had soldiers come up to me and say, 'You know, we're over here fighting for you and your family, and we need for you to go back home and fight for us.< And I knew exactly what they meant. It became a mission to me, a duty to come back here and do something to honor them. I didn't even think the song would get recorded - I just had something to say." (Darryl Worley; http://darrylworley.dreamworksnashoille.com/bio.HTM)

They took all the footage off my T.V.

Said it's too disturbing for you and me

It'll just breed anger that's what the experts say

If it was up to me I'd show it every day

Some say this country's just out looking for a fight

After 9/11 man I'd have to say that's right

Have you forgotten how it felt that day

To see your homeland under fire

And her people blown away?

Have you forgotten when those towers fell?

We had neighbors still inside

Going through a living hell

And you say we shouldn't worry 'bout Bin Laden

Have you forgotten?

I've been there with the soldiers / Who've gone away to war

And you can bet they remember / Just what they're fighting for

(Darryl Worley: »Have You Forgotten«, 2/2003)

"Country artist Darryl Worley is first out of the gate with a record that endorses war with Iraq. The top new song on this week's country chart at No. 43 Have You Forgotten? may seem to equate Saddam Hussein with Osama bin Laden, but the record is striking a chord. >Almost everybody that calls wants to know: a) where can I get it? and b) will you play it again right now? says Scott Lindy of WPOC-FM in Baltimore. [...] Worley says, [...] 'We're not trying to be politically correct. We're trying to put out a message that we believe everybody needs to hear, whether they agree with it totally or not.«"

(Brian Mansfield: „Country Anthem Plays a Drumbeat for War.«In: USA TODAY, 26.2.2003; http://www.usatoday.com/life/music/news/2003-02-25-anthem_x.htm) 
We ain't gonna give how you aim at us

'Cause deep in our hearts we will never let up

Terrorists around the world we're tearing you up

You can run all you want, you can't hide from us

USA - America - Respect us

USA - America - Respect us

It ain't gonna be no stoppin' us

We're puttin' it down

It ain't gonna be no stoppin' us

We're gonna get down

(MC Hammer: »No Stoppin' Us«, 11/2001)

Osama run home to your mama

We're coming after you

There'll be nothing but a bathrobe

And a beard when we get through

Your name is mud

For shedding blood

That ran red, white and blue

Osama run home to your mama

We're coming after you

(Bret Walton: »Osama Run Home To Your Mama«, 12/2001)

You stood on the front lines

You led the way, out of the darkness

You could have let us go astray

You were ready to die for our sake

And that takes a soldier's heart

(R. Kelly: »Soldier's Heart«, 4/2002 und 4/2003)

\section{R. KELLY - Patriotismus aus der Konserve}

New York (tk) - Der R'n'B-Sänger R. Kelly veröffentlicht am 23. April seine Single $\leadsto A$ Soldier's Heart«. Wie BBC berichtet, soll sie den Soldaten im Irak gewidmet sein. Den Gewinn des Verkaufs wolle Kelly durch seine »I Believe I Can Fly«-Foundation den Familien der Soldaten zukommen lassen. Die US-Presse kommentiert die Benefiz-Aktion kritisch: der Sänger wolle seinen Fans beweisen, dass er nicht der Perverse sei, als den ihn die Medien darstellten. Kelly steht schon seit längerem unter Verdacht, Sex mit Minderjährigen gehabt zu haben. Jetzt versucht er, sich erneut mit demonstrativem Patriotismus beliebt zu machen: "Der Song ist ein Tribut an die mutigen Soldaten und Soldatinnen, die ihr Leben riskieren, um den Frieden zu bewahren ", zitiert BBC den Soulsänger weiter. Im vergangenen Jahr hatte Kelly den gleichen Song schon einmal und ebenfalls am 23. April veröffentlicht. Damals ehrte er die Soldaten, die gegen den Terror kämpfen.

(Vor.Laut, 3. April 2003; http://www.laut.de/vorlaut/news/2003/04/03/04290) 


\section{»Let's roll!« (Flight 93)}

Let's roll America

It is our country's call

(Tony \& Shanne: »Let's Roll, America«, 9/2001)

We're all on the front lines now

Flight 93 has taught us how

(Mark A. Mandel: »No Safe Ground«, 2001)

Let's roll America

There's a job to be done

(The Bellamy Brothers: »Let's Roll America«, 7/2002)

Her forty brave souls all take heart,

"Let's Roll«, and fight for right!

America! America!

(Bette C. Ross: »America The Beautiful«, 9/2002)

I do believe before they hit the ground

From heaven came a great rejoicing sound

(Carl Dorsey \& Friends: »Thank You Flight 93«, 2002)

A whispered voice from one of us here:

»Are you guys ready? Let's roll."

(Mick Terry: »If We're Going Down (United Flight 93)«, 9/2001)

But our beautiful White House still lights up D.C.,

Thanks to those passengers on Flight 93

(Singers of Mad River Chorale: »Flight 93: The Spirit Of America«, 2002)

I wish we could be as courageous as the heroes on flight 93

(Grumbletummy: »Silent Vigil For The Missing «, 2001)

Let's roll, let's fight, let's show the world what's right

(dcTalk: »Let's Roll«, 9/2002)

And so the brave ones dared to say, »Let's roll!«

(Bruce Maccabee: »The Ballad Of 911«, 2002)

Are you ready, let's roll, let's take control

We know now what we gotta do

(Frontier Galaxies: »Flight `93««, 2002)

There's a hero in your soul

Let's roll

(Barry Preston: »Let's Roll«, 2002)

Time is running out

Let's roll

(Neil Young: »Let's Roll«, 11/2001) 


\section{Air Play}

\section{Country-Charts}

Country Music hat wohl den größten Anteil an 9/11-Songs. Viele davon wurden - im Gegensatz zu Songs anderer Genres - von Country Radiostationen gespielt.

\section{September 2001}

- Lee Greenwood: God Bless the USA, höchste Notierung: Platz 16

- Faith Hill: The Star-Spangled Banner, Platz 35

\section{Oktober 2001}

- Brooks \& Dunn: Only In America, Platz 1

- LeAnn Rimes: God Bless America, Platz 51

- Various Artists: America The Beautiful, Platz 58

- Randy Travis: America Will Always Stand, Platz 59

\section{Dezember 2001}

- Hank Williams Jr.: America Will Survive, Platz 45

- Charlie Daniels: This Ain't No Rag, It's A Flag, Platz 33

- Ray Stevens: Osama Yo-Mama, Platz 48

- Alan Jackson: Where Were You (When The World Stopped Turning), Platz 1

- Kenny Rogers: Homeland, Platz 39

\section{Januar 2002}

- Craig Morgan: God, Family and Country, Platz 49

- Aaron Tippin: Where The Stars And Stripes And The Eagle Fly, Platz 2

\section{Juli 2002}

- Toby Keith: Courtesy Of The Red, White \& Blue (The Angry American), Platz 1

Quelle: USA TODAY, 6. Sept. 2002 (http://www.usatoday.com/life/music/ 2002-09-05-sept11-country_x.htm).

\section{Hörerwïnsche nach 9/11}

Nach den Anschlägen waren die Hörerwünsche, die bei US-Radiostationen eingingen, ein Indikator für die Stimmung der Hörer. Die folgende informelle Umfrage belegt Reaktionen, so verschieden wie Radioformate.

WCBS-FM (101.1 FM, New York, Oldies)

- Ray Charles: America The Beautiful

- Brotherhood of Man: United We Stand

WSM (650 AM, Nashville, Traditional Country)

- Johnny Cash: Ragged Old Flag

WAAF (107.3 FM, Boston, Rock)

-Jimi Hendrix: Star-Spangled Banner

WAXQ (104.3 FM, New York, Classic

Rock)

-Don Henley: New York Minute

-Don McLean: American Pie

- Supertramp: Crime Of The Century

- John Lennon: Imagine

- Simon and Garfunkel: Bridge Over Troubled Water

-U2: Pride

- John Mellencamp: Peaceful World

WHTZ (100.3 FM, New York, Top 40)

- Enrique Iglesias: Hero

- Jewel: Hands

- Lee Greenwood: God Bless The U.S.A.

KROQ (106.7 FM, Los Angeles, Rock)

- System of a Down: Chop Suey

- Alien Ant Farm: Smooth Criminal

- Jimmy Eat World: Bleed America

WLZR (103.0 FM, Milwaukee, Rock)

- Pearl Jam: Rockin' In The Free World

- Metallica: Don't Tread On Me

- Limp Bizkit: Break Stuff

Quelle: The New York Times, 1. Okt. 2001 (http://www.whitneyfan.com/nr/misc/ 2001/079.shtml). 


\title{
Vernetzung, Verschwörung
}

\begin{abstract}
(George W. Bush-Imitation:)
"Good evening, I would like to report on the state of our war against the American people. We're mounting a sustained campaign, a crackdown on every American and every person of every faith in every nation, and to bring them to justice. All missions are being executed according to plan; without warning or provocation Americans are being swept up in an international dragnet. Thousands of FBI agents are on the trail of other citizens here and abroad. It has everything to do with hate and evil and murder and prejudice. America is strong...«
\end{abstract}

What would you do if you - 911Timeline.net

Knew all of the things we know - AttackOnAmerica.net

Would you stand up for truth - Lovearth.net

Or would you turn away too? - Sold-Out.net

And then what if you saw - September112001.net

All of the things that's wrong - UnitedStatesGovernment.net

Would you stand tall and strong? - MyCountryRightOrWrong.net

Or would you turn and walk away - ConcentrationCamps.net

Now ask yourself who's the people with the most to gain (Bush) - Richest.net

'Fore 911 motherfuckas couldn't stand his name (Bush) - Corpocracy.net

Now even brothas waivin' flags like they lost they mind - Drug-Companies.net

Everybody got opinions but don't know the time - Police-State.net

'Cause Amerikkka's been took - it's plain to see - eAmerica.net

The oldest trick in the book is make an enemy - Misinformation.net

Of phony evil now the government can do its dirt - Lies.net

And take away ya freedom lock and load, beat and search - SneakAndPeek.net

Ain't nothin' changed but more colored people locked in prison - Prisons.net

These pigs still beat us but it seem we forgettin' - Conspiracies.net

But I remember 'fore September how these devils do it - Trilateral-Commission.net

Fuck Giuliani ask Diallo how he doin' - Racism.net

We in the streets holla »jail to the thief « follow - CouncilOfForeignRelation.net

Fuck wavin' flags bring these dragons to they knees - Federal-Reserve.net

Oil blood money makes these killers ride cold - OilCompanies.net

Suspicious suicides people dyin' never told - Assassinations.net

It's all a part of playin' God so ya think we need 'em - Oligarchy.net

While >Bin Ashcroft< take away ya rights to freedom - Fascistic.net

Bear witness to the sickness of these dictators - AlternativeNews.net

Hope you understand the time brother cause it's major - WorldWarIII.net

(Paris: »What Would You Do?«, 3/2002)

"All 65 websites hot-linked are part of the Lovearth Network. Learn the truth about 911 and the new world order globalization take-over plans. Every line is hot-linked to a website which is relevant to the meaning of that line. What would you do - Go through these 65 websites and learn - or turn away?«

(http://www.911timeline.net/whatwouldyoudo.htm) 
"Two media activists $\mathcal{E}$ artists from C-Supreme Studios in NY, have created a hip-hop-rock song dealing with the unanswered questions concerning the Sept. 11 attacks. The song is based on info gleaned from www.unansweredquestions.org and www.gnn.tv."

(http://www.delcanton.com/cds/kaneandsalem.asp)

\author{
Ahmed is buddy-buddy with George Tenet \\ He's buddy-buddy with Mohammed Atta
}

At 8:28 A.M. Flight 11 makes an unplanned 100 degree turn to the south

At 9:04 our commander \& chief is told:

»A second plane has hit, America is under attack"

He is in an elementary school

And continues to read about goats for the next 20 minutes or so

Meanwhile

Secret Service whisk Dick Cheney into an underground presidential bunker

8:50 AM there is a loss of contact with a plane detoured off course to the capital

But it wasn't till 9:24 A.M. that American Fighters were scrambled: do the math

This is 34 MINUTES after flight control lost contact with the plane

And long after two planes have already crashed:

The 11th wasn't the first time a hijack ever took place in America

Never has there been this long a delay, when any other flights were hijacked

10 minutes is the maximum allowed

34 minutes is unprecedented

This is 24 minutes that made the difference in allowing an attack on the Pentagon

And who gets the blame?

Richard Myers was promoted to Chairman of the Joint Chiefs of Staff

The highest military office in the country

After the worst attack on America was perpetrated under his watch

There must have been a military order

There must have been a military order

There is no other logical explanation for 34 minutes

When only 10 are legally allowed

Meanwhile

Chairmen of (Congressional) Intelligence Committees are having breakfast

With Mahmoud Ahmed, head of the Pakistani ISI

Who had authorized a $\$ 100,000$ wire transfer to Mohammed Atta

The alleged ringleader of the 9-11 attacks

There must have been a military order

There must have been a military order

There is no other logical explanation for 34 minutes

When 10 are only legally allowed

Ahmed is buddy-buddy with George Tenet

He's buddy-buddy with Mohammed Atta, he's buddy-buddy with... (repeat to end)

(Anti-C: »Buddy Buddy (Well, Well, Well, My Michel)«, 2002) 


\section{Not In Our Name}

It's in the paper every day

You see it in the headlines and you feel so sick

As another life leaves this world - this world so full of hate - but short!

Short on compassion, short on humanity

Asking myself in vain, shaken by the shock

»Do we even have a chance?«

I don't want to die

I don't want to kill

We are all human

It's time to prove it

(Anti-Flag: »911 For Peace«, 2/2002)

Hey yo, the ants still steal

The anthrax got my whole earth wearin' a mask and gloves to get a meal

I know a older guy that lost twelve close peeps on 9-1-1

While you kickin' up punchlines and puns

Man fuck that shit, this is serious biz

By the time Bush is done, you won't know what time it is

If it's war time or jail time, time for promises

And time to figure out where the enemy is

The same devils that you used to love to hate

They got you so gassed and shook now, you scared to debate

The same ones that traded books for guns

Smuggled drugs for funds

And had fun lettin' off forty-one

But now it's all about NYPD caps

And Pentagon bumper stickers

But yo, you still a nigga

It ain't right them cops and them firemen died

The shit is real tragic, but it damn sure ain't magic

It won't make the brutality disappear

It won't pull equality from behind your ear

It won't make a difference in a two-party country

If the president cheats, to win another four years

Now don't get me wrong, there's no place I'd rather be

The grass ain't greener on the other genocide

But tell Huey Freeman don't forget to cut the lawn

And uproot the weeds

Cuz I'm not satisfied. . .

Whoever told you that it was all good lied

So throw your fists up if you not satisfied

All this genocide is not justified

Are you satisfied? I'm not satisfied

(J-Live: »Satisfied «, 4/2002) 
Mustapha, Mazeltov, the Gaza Boys, all that holy stuff

I got the feelin' when it all goes off

They're gonna shoot the dog, they're gonna shoot the dog

So, Cherie my dear, could you leave the way clear for sex tonight?

Tell him »Tony, Tony, Tony, I know that you're horny

But there's somethin' 'bout that Bush ain't right"

Nine, nine, nine, gettin' jiggy

People, did you see that fire in the city?

It's like we're fresh out of democratic

Gotta get yourself a little, something semi-automatic, yeah

That's why I'm always gettin' stoned, yeah

That's why I'm out there havin' fun again

Good puppy, good puppy, rollin' on over for The Man

The Ayatollah's gettin' bombed, yeah

See Sergeant Bilko having fun again

Good puppy, good puppy, rollin' on over for The Man

(George Michael: »Shoot The Dog«, 8/2002)

"I have strong opinions on Britain's current situation and I fell that in a time when public debate is being suppressed, even something as trivial as a pop song can be a good thing. shoot The Dogr is intended as a piece of political satire, no more no less, and I hope that it will make people laugh and dance, and then think a little, that's all."

(George Michael; http://members.ozemail.com.au/ alhatu/std-state.htm)

»Oh where are you going?« said the man at his desk

"I'm going to a new world, « said the child and he stood

And he stood, and he stood, and t'were well that he stood

"I'm going to a new world, « said the child and he stood

»Oh I'm sounding drums of war, « said the man at his desk

»Oh, I will not fight your war, « said the child and he stood

And he stood, and he stood, and t'were well that he stood

"I will not fight your war, « said the child and he stood

»Oh, but don't you love your country? « said the man at his desk

"Yes, I do, but you don't, « said the child and he stood

And he stood, and he stood, and t'were well that he stood

"I do but you don't, « said the child and he stood

(Stephan Smith: »The Bell«, 9/2002)

Know your enemy, know yourself

That's the politic

George Bush is way worse than bin Laden is

Know your enemy, know yourself

That's the politic

C.I.A., F.B.I. the real terrorists

(Dead Prez: »Know Your Enemy«, 11/2002) 
"The famous Vietnam War protest anthem written and performed by Country Joe McDonald at the historic Woodstock concert in 1969, has been re-released with updated lyrics to serve the rapidly growing anti-Iraqi War movement. The single titled, >The Iraqi War Song< or >Feel Like I'm Smellin' A Rat Rag, is a parody of the original >Feel Like I'm Fixin' To Die Rage that became the srallying cry< of the hippie and baby-boomer generations. The song helped bring an end to the Vietnam War.

The new lyrics were written and sung by an award winning health science writer and leading critic of the Bush administration's emergency preparedness plans for domestic bioterrorism, Dr. Leonard Horowitz. The heavily credentialed doctor is currently working with Amnesty International officials in support of their developing HIV/AIDS human rights petition. He conceived of the project and contacted Joe McDonald (of >Country Joe and the Fish<) for support, which the folk hero freely granted."

(http://www.healingcelebrations.com/iraqiwarsong.htm)

And it's one, two, three, what are we fighting for

Most know it's the same old scam, Wag-the-dog at old Sadam

And it's five, six, seven, open up the pearly gates

Well, we've got no time to wonder why, whoopee we're all gonna die

So come on mothers throughout the land

Pack your boys off to old Bhagdad

Come on fathers don't hesitate

Send your girls too before their wedding date

Be the first ones on your block

To have your kids come home in a box

And it's one, two, three, what are we fighting for

The clueless just don't give a damn, about the oil in Afghanistan

And it's five, six, seven, open up the pearly gates

Well, Rockefeller says the population's too high, and half of us need to die

So come on all of you dumbed down men

The son of a Bush needs your help again

He's got us all in a terrible jam

Ousting daddy's partner old Sadam

So don't roll up your sleeves for any shots in your arm

It's just smarter to stay on the farm... That's all!

(Country Bumpkin \& The Hogs:

»The Iraqi War Song - Feel Like I'm Smellin' A Rat Rag«, 9/2002)

Country Joe McDonald: »I-Feel-Like-I'm-Fixin'-To-Die-Rag« (1965)

in Afghanistan (http://www.countryjoe.com/afghan_fixins.htm):

"The Anti-Terrorism Rag"• »Feel Like I'm Fixin' To Murder Rag"• "I-Feel-Like-WereGonna-Kick-Some-Ass-Rag"•»I Feel Like I'm-A Fixin' To Scud Rag"• »Fixin' To Die In

Afghanistan" • "Fixin' To Die Again Rag" • "The Bush Jeer And Dubya Is Fixing-A-Lie

Rag $\bullet \cdot \ldots$

und im Irak (http://www.countryjoe.com/iraq_fixins.htm):

»I Feel Like I'm Fixin' To Die Rag, Part 2«• »Fixin To D'Iraq Rag« • The Itching To

Strike Rag" • »Thirsty For Oil Rag • »Fixin' To Lie Rag" $\bullet . .$. 


\section{War Is Not The Answer}

We don't want your war

Let's yell a little louder now

We don't want your war

All stand together tall

We don't want your war

But you keep telling us, you keep telling us we do

(Jynkz: »We Don't Want Your War«, 2/2003)

»Released via the Internet on the evening of President Bush's State of the Union address, $>W e$ Don't Want Your War by independent musician Jynkz is quickly becoming a hit with war opposition groups. With almost 10,000 downloads to date, protesters from San Francisco to Stockholm are rallying around the artist's anti-war chant. [...] As more people become increasingly frustrated and angry with President Bush's crusade for war, the world turns to the Internet to unite, discuss and even find music that brings solace."

(http://www.emediawire.com/releases/2003/2/prweb56455.htm)

Ecoute, Ecoute, Ecoute, une seule condition

Shalom ou Salam peuvent être la mission pacifique

Ecoute, Ecoute, Ecoute, au delà d'une religion des coups

Shalom ou Salam, Bom Shankar, quelle que soit ta vision,

Ecoute, Ecoute, Ecoute, une mission multiculturelle

Shalom ou Salam peuvent être une mission pacifique

Ecoute, Ecoute, Ecoute, la mission primordiale c'est la Paix

je dis la Paix...

(Le Peuple de l'herbe: »Chienne2Guerre«, 1/2003)

It's not a war on terrorism, it's a war of terrorism

The old imperialism

You know the money is the reason

America is killing for oil, not for freedom

(The Dope Poets Society: »War Of Terrorism«, 2/2003)

We need health care more than going to war

You think it's democracy they're fighting for?

In a world gone mad it's hard to think right

So much violence hate and spite

Murder going on all day and night

Due time we fight the non-violent fight

(Beastie Boys: »In A World Gone Mad ...«, 3/2003) 
Frère pose les armes, essuie tes larmes, donne du love

La Paix, la Paix, la Paix

qu'on veut pour soigner nos blessures

L'amour, l'amour, l'amour

qu'on attend depuis des années, des mois et des jours

(Sergent Garcia feat. Bionik: »Stop Da War«, 2/2003)

Se você já sabe

Quem vendeu

Aquela bomba pro Iraque

Desembuche:

Eu desconfio que foi o Bush

Foi o Bush, foi o Bush, foi o Bush

(Tom Zé: »Companheiro Bush«, 3/2003)

Soldaten gaan naar huis en zijn de zogenaamde helden

Opscheppers in de bar waar ze een mooi verhaal vertellen

En zijn vrienden denken allemaal ja hoor het zal wel goed zijn

En een vrouw stervend op straat denkt alleen aan Sadam Hoessein

(VSOP: »Machteloos«, 3/2003)

The solution is simple and plain

There won't be peace if we don't try

In a war there is nothing to gain

And so many people will die

We want peace, we want it

Yes, we want peace, we want it

Yes, we want peace

And we want it fast

(Lenny Kravitz \& Karem Al Sahir: »We Want Peace«, 3/2003)

\section{Lenny Kravitz - Scharfe Kritik an Friedenssong}

New York (ebi) - Es habe viele seltsame Reaktionen auf "We Want Peace " gegeben, ließ Lenny Kravitz verlauten. "Sehr aggressiv, sehr hasserfüllt. Viele Leute scheinen ein Problem damit zu haben, dass ein Iraker bei dem Stück mitwirkt«, diagnostiziert der Musiker dem Spiegel zufolge. Kravitz hatte den gemeinsam mit dem bekannten Iraker Kadim el Sahir, dem palästinensischen Gitarristen Simon Schaheen und dem libanesischen Percussionisten James Haddes eingespielten Song Ende März via Web veröffentlicht.

"Aber heißt diese Aktion nicht >Iraqi Freedom<? Wir sind also da drüben, um die Leute zu befreien und gleichzeitig darf man nichts mit ihnen zu tun haben?", wundert sich Kravitz. Viele Amerikaner hielten den Song zudem für ein Anti-Kriegs-Stück, so der 38-Jährige weiter. Deshalb würden ihn viele Radiostationen aus Angst vor einbrechenden Einschaltquoten nicht spielen.

(Vor.Laut, 16. April 2003; http://www.laut.de/vorlaut/news/2003/04/16/04335/index.htm) 
Boom! Boom! Boom! Boom!

Everytime you drop the bomb you kill the God your child has born

Boom! Boom! Boom! Boom!

(System of a Down: »Boom!«, 3/2003)

In guerra non andate, di farla rifiutate all'ordine di partire rifiutarsi d'obbedire!

(Terminale X: »Il disertore«, 3/2003)

What's wrong with the world, mama

People livin' like they ain't got no mamas

I think the whole world addicted to the drama

Only attracted to things that'll bring you trauma

Overseas, yeah, we try to stop terrorism

But we still got terrorists here livin'

In the USA, the big CIA

The Bloods and The Crips and the KKK

But if you only have love for your own race

Then you only leave space to discriminate

And to discriminate only generates hate

And when you hate then you're bound to get irate, yeah

Badness is what you demonstrate

And that's exactly how anger works and operates

Nigga, you gotta have love just to set it straight

Take control of your mind and meditate

Let your soul gravitate to the love, y'all, y'all

People killin', people dyin'

Children hurt and you hear them cryin'

Can you practice what you preach

And would you turn the other cheek

Father, Father, Father help us

Send us some guidance from above

'Cause people got me, got me questionin'

Where is the love?

(Black Eyed Peas feat. Justin Timberlake: »Where Is The Love?«, 7/2003)

Suddenly it's over, the war is finally done

Soldiers in the desert sand, still clingin' to a gun

No-one is the winner an' everyone must lose

Suddenly the war is over: that's the news ...

That's the news, that's the news

That's the ever-lovin', blessed, headline news

Politicians do all the talkin': soldiers pay the dues

Suddenly the war is over, that's the news

(Merle Haggard: »That's The News«, 7/2003) 


\section{Top 10 Anti-War/Protest Songs by Popular Artists}

1) Beastie Boys: In A World Gone Mad ...

Posting to their official web site Adam H. of the Beastie Boys states, "This song is not an anti-American or pro-Saddam Hussein statement. This is a statement against an unjustified war.«...

\section{2) Madonna: American Life}

From the lyrics alone the newest Madonna song doesn't appear to be anti-war. The chorus goes "American life... you are the best thing I've seen, you are not just a dream «. It is the video that is making a statement. . .

\section{3) Spearhead: Bomb Da World}

An early release from the forthcoming album Everybody Deserves Music, the lyrics to Bomb Da World offer real wisdom, "You can bomb the world to pieces, but you can't bomb it into peace." Easily the best of the new anti-war songs, this song is a gentle sermon on the evils of war...

\section{4) System of a Down: Temper}

This song protests the idea of blood for oil, "Invade countries just for oil, send your troops all down to boil «, making it a very timely song. Written as a demo in 1996, the song is not on any SOAD album, but is easily found on the web...

\section{5) Billy Bragg: The Price Of Oil}

This song by activist-musician Billy Bragg is all about the current Iraqi-US conflict. The opening lyrics "The allies won't approve the plan, but the oil men in the white house they just don't give a damn, it's all about the price of oil « come right from popular activist sentiment...

\section{6) Sleater-Kinney: Far Away}

Written about the 9/11 terrorist attacks, this song speaks of the aftermath for the world and the legacy of war the attacks have brought. The lyrics "Don't breathe the air today, don't speak of why you're afraid... No other direction for this to go, and we fall down" predict doom for all if war is the answer to 9/11. A moody yet beautiful song in a time of world crisis.

\section{7) Public Enemy: Son Of A Bush}

More anti-Bush than anti-war, this song was first released in 2002. A protest of the US government under G.W. Bush, the song speaks to the anger many people feel over the war with Iraq . . .

8) Chumbawamba: Jacob's Ladder (Acoustic Remix)

A previously unreleased acoustic version of the song Jacob's Ladder, this song could have been written yesterday. The opening lyrics »like a sermon on the mountain, hellfire and brimstone, swapped for oil and guns « say what many feel this latest Iraqi-US war is really about...

\section{9) Ms. Dynamite: Watch Over Them}

This sad and soulful song was originally written as a lament of black on black street violence, with lyrics like »We should be protecting instead we're de-stroying, oh Father watch over them ", it seems a fitting addition to this list...

\section{0) Outkast: B.O.B. (Bombs Over Baghdad)}

Outkast have joined the growing list of artists opposed to war, and it is not just a publicity pull, for this band it goes way back. This song from the 2000 CD Stankonia is an angry lament about the price of war...

(Tina Kells in: About.com - Music for Teens, o.D. [April 2003]; http://teenmusic.about.com/cs/toppicks/tp/blantiwar1.htm) 